\title{
Potential Molecular Mechanisms of the Anti-cancer Activity of Vitamin D
}

\author{
DOROTA SKRAJNOWSKA and BARBARA BOBROWSKA-KORCZAK
}

\author{
Department of Bromatology, Medical University of Warsaw, Warsaw, Poland
}

\begin{abstract}
Vitamin D, or more precisely its active metabolite calcitriol $\left(1,25-(\mathrm{OH})_{2} \mathrm{D}_{3}\right)$, plays a fundamental role in bone metabolism and differentiation as well as in intestinal absorption of calcium and regulation of calcium-phosphate metabolism. Recent decades have brought about the discovery of the role of calcitriol in processes regulating cell differentiation, proliferation, angiogenesis and apoptosis. This creates the potential for numerous therapeutic applications of vitamin $D$ in diseases associated with autoaggressive immune responses or in cancer. This study presents selected issues regarding current knowledge of the anti-cancer mechanisms of vitamin D.
\end{abstract}

The discovery that most tissues have receptors for vitamin $\mathrm{D}$ was a breakthrough in understanding its role in cancer development. A long-term vitamin D deficiency probably increases the risk of cancer (1-5). The hypothesis that vitamin $\mathrm{D}_{3}$ deficiency is linked to cancer development is supported by the results of experiments on animal models as well as epidemiological studies investigating the relationship between exposure to UVB radiation and cancer survival (68). Vitamin D protects the genome against the accumulation of mutations underlying neoplastic transformation and cancer progression. At the same time, owing to the anti-tumour activity of calcitriol and its analogues, these compounds can be used alone (promyelocytic leukaemia) or in synergy with other anticancer drugs, mainly cytostatics $(9,10)$. This means that the dose of cytostatics can be reduced, thereby reducing the risk of side effects following chemotherapy. For example, treatment with calcitriol in combination with carboplatin, dexamethasone or paclitaxel has been proven

Correspondence to: Barbara Bobrowska-Korczak, Department of Bromatology, Medical University of Warsaw, Banacha 1, 02-097 Warsaw, Poland. Tel/Fax: +48 225720785, e-mail: barbara.bobrowska@ wum.edu.pl

Key Words: Vitamin D, nVDR receptor, antitumor effect, review. effective against both androgen-dependent and androgenindependent prostate cancer $(10,11)$. As in the case of prostate cancer (PCa), the therapeutic efficacy of calcitriol has also been confirmed in both hormone-dependent (oestrogen-receptor-positive) and oestrogen-receptornegative breast cancer (12), as well as colorectal and head and neck cancer (13-17). The mechanism of the antineoplastic activity of vitamin $\mathrm{D}$ and its derivatives may vary depending on the type of cells and tissues. The excessive supply of calvium is itself considered by some researchers to be a PCa risk factor, and a low concentration of vitamin $\mathrm{D}$ may additionally increase the risk of prostate cancer by reducing production of $1,25-(\mathrm{OH})_{2} \mathrm{D}_{3}$. Moreover, a high concentration of $\mathrm{Ca}$ may inhibit the release of $\mathrm{PTH}$ (parathyroid hormone), which regulates the conversion of $25(\mathrm{OH}) \mathrm{D}_{3}$ to $1,25-(\mathrm{OH})_{2} \mathrm{D}_{3}$ in the kidneys $(18)$.

Thus, there is a clear dependency between calcium supply and the concentration of $25(\mathrm{OH}) \mathrm{D}_{3}(19,20)$. The mechanism of the biological activity of calcitriol is still quite difficult to explain, because the degree of inhibition of proliferation, apoptosis and cell cycle arrest depends on many different factors, primarily the degree of cell differentiation, the occurrence of growth factors, the dosage of vitamin $\mathrm{D}$, and calcium concentrations in the intraand extracellular environment.

\section{Vitamin D - Cell Cycle Regulation}

The growth and proliferation of hormone-dependent epithelial cells in health and disease depend on many intracellular signal transmission pathways. The signalling pathways may be activated by insulin-like growth factor 1 or 2 (IGF-1, IGF-2) or epidermal growth factor (EGF) and by pro-inflammatory cytokines such as tumour necrosis factor (TNF), interleukin-2 (IL-2) or granulocyte-macrophage colony-stimulating factor (GM-CSF). There are also pathways specific for tumours, called proliferative signalling pathways (21). The activation of transcription signalling pathways results in the modulation of numerous target genes which regulate proliferation of cells and genes influencing processes which mediate cell transformation 
in normal and proliferative tissues, such as inflammation, angiogenesis, cell mobility, and the ability to metastasize. These may lead to cell transformation and tumour formation. Vitamin D, primarily, influences calcium and phosphate balance, but in recent years a number of publications have highlighted its multi-faceted activity associated with the presence of the vitamin D receptor (VDR), including an antitumour effect (22). Although several mechanisms have been suggested to explain the inhibitory effect of $1,25(\mathrm{OH})_{2} \mathrm{D}_{3}$ on the cell cycle, no convincing data have been presented on the primary mechanism of the regulation of cell division. The most commonly mentioned mechanisms of cell cycle regulation by vitamin D are presented below.

In order for the cell to pass from phase $G_{1}$ to phase $S$, in which DNA synthesis takes place, retinoblastoma $(\mathrm{Rb})$ protein phosphorylation is required to activate transcription factors of the E2F family, which activate transcription of many genes, including cyclins $\mathrm{E}$ and $\mathrm{A}$. Rb phosphorylation is catalysed by specific cyclin-dependent kinases (CDKs), whose activity is inhibited by $\mathrm{p} 21$ and $\mathrm{p} 27$ proteins. The complex of $1,25(\mathrm{OH})_{2} \mathrm{D}_{3}$ and VDR binds to the regulatory site in the promoter region of the $\mathrm{p} 21$ and $\mathrm{p} 27$ genes, intensifying their expression, which leads to inhibition of CDKs, lack of $\mathrm{Rb}$ phosphorylation, and cell-cycle arrest in the $\mathrm{G}_{1}$ phase $(23,24)$. The antiproliferative effect of vitamin $\mathrm{D}$ also involves modulation of intracellular kinase pathways (p38 MAPK P38 mitogen-activated protein kinases, ERK - extracellular signal-regulated kinases, and PI3K - phosphoinositide 3kinase) and repression of the proto-oncogene Myc, which plays the key role in cell proliferation (24).

$1,25(\mathrm{OH})_{2} \mathrm{D}_{3}$ and its analogues are known to cause rapid and concentration-dependent $\left(10^{-10}-10^{-8} \mathrm{M}\right)$ activation of phospholipase $\mathrm{C}$, which is responsible for the hydrolysis of inositol lipids. This results in activation of protein kinase $\mathrm{C}$ (PKC) which plays an important regulatory in the control of gene expression; activates expression of the gene encoding Raf1 - a kinase of mitogen-activated kinase (MAPK). This is followed by an increase in the activity and phosphorylation of two members of the kinase family, MAPK-1 and MAPK-2, associated with regulation of the growth of many cells (25). In the context of long-term processes, PKC plays a significant role in cell differentiation, mobility and metastasis $(2,12)$.

The anti-proliferative effects of $25(\mathrm{OH}) \mathrm{D}_{3}$ correlate with the expression of endogenous 1- $\alpha$-hydroxylase, whose activity is reduced in cancer cells compared to healthy prostate cells $(5,26,27)$. The discovery of reduced activity of 1- $\alpha$-hydroxylase in prostate cancer (PCa) epithelial cells provided an explanation for the locally reduced production of $1,25(\mathrm{OH})_{2} \mathrm{D}_{3}$, which results in the inhibition of cell differentiation and an increase in cancer invasiveness (27).

Another type of interaction of regulatory pathways caused by activation of the EGF (epidermal growth factor) receptor is the induction of other biological processes (apart from proliferation) in tumour transformation, such as inflammation, tumour angiogenesis, and infiltration, through stimulation of cyclooxygenase $2(\mathrm{COX}-2)$ and production of prostaglandin PGE2 $(28,29)$. It has been demonstrated that calcitriol may also inhibit the activity of cellular growth stimulators - prostaglandins. It has been shown that treatment of theprostate cancer cell line $\mathrm{LNCaP}$ with $1,25(\mathrm{OH})_{2} \mathrm{D}_{3}$ limits PGE2 synthesis (through inhibition of COX-2) and increases its inactivation (by stimulating prostaglandin dehydrogenase (15-PGDH), which transforms prostaglandins into ketone derivatives) (29).

Other mechanisms of cell cycle regulation by $1,25(\mathrm{OH})_{2} \mathrm{D}_{3}$ involve inhibition of mitogenic signals transmitted by growth factors such as EGF and stimulation of the pathways of transforming growth factor $\beta$ (TGF- $\beta$ ) and insulin-like growth factor-binding proteins (IGF-BP), e.g. IGF-BP3 (30), as well as the aforementioned reduction of the expression of $c-M y c$ gene, which plays a significant role in cell proliferation. In normal cells, the expression of c-Myc gene is correlated with an increase in the concentration of the c-Myc protein. This leads to metabolic disorders and tumour formation. Abnormal oncogene structure has been observed in many tumours.

Moreover, in cells exposed to calcitriol analogues, a reduction has been observed in the activity of ornithine decarboxylase, an enzyme necessary for DNA synthesis, as well as a decrease in the secretion of IL-6 (interleukin-2) and IL-8 (interleukin-8), which are known mitogens for keratinocytes (31).

One of the characteristic features of tumour cells is increased activity of telomerase. The enzyme is active in about $80-90 \%$ of all tumours and is responsible for the reconstruction of telomeres. It is a specialized DNA polymerase with reverse activity to that of transcriptase, which synthesises telomeric repetitions de novo $(32,33)$. The enzyme is composed of two key sub-units: a sub-unit consisting of an RNA chain (reverse transcriptase, RT) and the equally important sub-unit telomerase reverse transcriptase (TERT) (33-35). TERT has the ability to elongate telomeres in order to maintain the integrity of chromosomes, and in some sense regulates cell life span (34). It plays a significant role in proliferation, differentiation, carcinogenesis and ageing of cells (35). The RT and TERT sub-units together make up the enzyme core. Calcitriol and its analogues inhibit the high telomerase activity seen in human cancer cells by decreasing TERT mRNA expression. Induction of miR 498 gene by calcitriol is implicated in the down-regulation of TERT mRNA in some cancer cells (24).

\section{Nuclear Vitamin D Receptor (nVDR)}

Vitamin D initiates or suppresses the transcription of genes after binding to its receptor, VDR, which belongs to the nuclear receptor superfamily and acts as a ligand-activated transcription 
factor $(1,5)$. It is composed of the conserved N-terminal DNAbinding domain and an $\alpha$-helical $\mathrm{C}$-terminal ligand-binding domain. Binding of calcitriol to the ligand-binding domain causes heterodimerization of VDR with retinoid X receptor (RXR). This is necessary for binding to a DNA sequence known as the vitamin D response element (VDrE), located in the promoter region of the $1,25(\mathrm{OH})_{2} \mathrm{D}_{3}$ target genes $(36,37)$. These include the genes for amphiregulin - an epithelial growth factor stimulating the development of head and neck, and breast cancer $(15,38)$, the cell cycle inhibitor protein $\mathrm{p} 21$, apoptosis regulator protein bcl-2, and p53, a protein suppressing oncogenes that control cell growth, such as c-fos (39). Following binding to certain VDrE sequences and activating proteins, VDR acts as a transcription factor, inducing cell growth and proliferation as well as apoptosis (5). A significant discovery was the presence of VDR in cancerous cells, including breast cancer cells (40), which suggests that these cells may be susceptible to the effects of vitamin D. Advanced research is currently underway to introduce calcitriol and especially its analogues in the treatment of patients with breast, prostate, colorectal and head and neck cancer, as well as in combination therapy that is already used for acute promyelocytic leukaemia $(9,13,15,41-45)$. On the other hand, subtle allelic variations of the VDR gene located on chromosome $12(12 \mathrm{q} 13.1)$ are relatively common in the population (46). It has been demonstrated that polymorphisms in the VDR gene can play a significant role in the formation of cancers (47-49). Thus far, over 60 different polymorphisms localized in the promoter region, the region of exons $2-9$, and the 3'UTR region have been detected. These can be single nucleotide polymorphisms (SNP) or functional polymorphisms, but also repeats (e.g. BsmI (G/A) (rs1544410), ApaI (G/T) (rs7975232), TaqI (T/C) (rs731236), Fok1 or Poly (A) in the 3'UTR region) (50). All changes in VDR can affect mRNA stability, and hence the translation of VDR mRNA. For example, the GG genotype of the ApaI (G/T) polymorphism influences the efficacy of chemotherapy in patients with nonsmall cell lung cancer (NSCLC). The authors of the study even suggested that the ApaI polymorphism in the VDR gene may prove to be a good marker for the use of individualized chemotherapy for NSCLC (51).

Thus, both normal and mutant VDR receptors are very important factors in the activity of vitamin $\mathrm{D}$ and its analogues in the process of tumorigenesis.

\section{Vitamin D - Apoptosis Induction}

Another possible pathway of the anti-tumour function of calcitriol is apoptosis induction, which has been demonstrated in tumour cells of the prostate, breast and large intestine (22, 52). However, the exact mechanism of this activity has not yet been identified. During apoptosis, the cell undergoes biochemical changes involving expression of specific genes (bax, bcl-2, TRPM-2/clusterin, cathepsin B) as well as morphological changes (cytoplasm condensation, DNA fragmentation or the formation of apoptotic bodies) $(39,53)$. Vitamin D treatment of colon cancer cells activates the expression of cystatins, endogenous inhibitors of cysteine proteases of the cathepsin family (54). Cathepsin B participates in the carcinogenesis process on many levels of tumour transformation, invasion and metastasis. Cathepsin B has been shown to enter into the cell nucleus and activate apoptosis (55). Most research studies have confirmed that the activity of cysteine endopeptidases can be measured as marker of tumour aggressiveness and their inhibitors as markers in diagnosis and monitoring of cancer therapy (56-58). In prostate epithelial cells, clusterin expression increases immediately after castration, reaching its maximum level in rat prostate cells 3-4 days after the procedure, which is associated with the beginning of mass cell death. At the same time, clusterin may be a marker of cell death and an apoptosis promoter. According to Zhu et al. (59), vitamin D may express its antitumoral effect by mediating the MEG3/clusterin signaling pathway. Proteins belonging to the bcl-2 family (Bcell CLL/lymphoma 2) play the key role in apoptosis regulation. Despite the similarity in their structure, different proteins in this family play opposite roles in the regulation of apoptosis. They may block apoptotic signals or cause an increase in the permeability of the external mitochondrial membrane to release of cytochrome $\mathrm{c}$ and activate caspases and cell death (60-62). Moreover, in the early stages of carcinogenesis, over-expression of protein bcl-2 protects cells with lethal mutations and contributes to genetic destabilization, a characteristic of tumours (62). The reduced efficiency of apoptosis in tumour cells may also be linked with mutations in the bax gene, one of the main effectors of p53induced apoptosis (63). The co-dependency between the occurrence of TP53 gene mutations in cancers and disordered balance of the expression of bcl-2-bax is very often observed (64). Calcitriol has been found to decrease Bcl-2 expression in breast cancer cell lines (65). Ohnishi et al. have shown that vitamin D-induced cell-cycle arrest is mediated by inhibition of several key proteins which regulate the $G_{1} / S$ phase and by up-regulating TP53 expression (66).

\section{Vitamin D - Inhibition of Invasiveness and Metastasis of Tumours}

The colonization of tissues by tumour cells does not seem to be accidental. Tumour cells show some preferences for settling in a given organ (67). This probably takes place due to chemotaxis of tumour cells in connection with the level of cytokines produced by the cells, due to exceptionally favourable environmental conditions in the organ or to selective adhesion of tumour cells into the endothelial cells of the vessels in the organ. The over-expression of some 
integrins suggests that integrins are the main molecules involved in selective adhesion (68). In vivo research on animal models of prostate and bladder tumours has shown that $1,25(\mathrm{OH})_{2} \mathrm{D}_{3}$ reduces the invasiveness of tumours (6971). Suggested mechanisms of the 'anti-invasive' function of vitamin D include inhibition of metalloproteinase and serine protease activity and increase E-cadherin expression, as well as reduction of the expression of integrins a6 and b4. E-cadherin belongs to the superfamily of calcium-dependent adhesion molecules. Changes in the expression and regulation of these proteins are strictly linked to tumour invasiveness. The loss of E-cadherin activity has been correlated with the clinical level of prostate cancer malignancy and the capacity to metastasize, as well as with poor overall survival of patients (72-74).

\section{Vitamin D - Angiogenesis Inhibition}

Another anti-tumour mechanism that has been described for $1,25(\mathrm{OH})_{2} \mathrm{D}_{3}$ is the inhibition of angiogenesis, e.g. in prostate cancer, both directly through the impact of tumour endothelial cells and indirectly through a reduction in the amount of COX-2-generated prostaglandin E2 (PGE2) $(24,31)$. One of the factors which induce angiogenesis is IL-8. The main functions of IL-8 are chemotactic attraction of neutrophils to the site of inflammation and stimulation of their bactericidal properties. Moreover, IL-8 plays a crucial role as an agent stimulating the formation of new blood vessels. In prostate cancer cells, $1,25(\mathrm{OH})_{2} \mathrm{D}_{3}$ has been shown to inhibit the activation of $I L-8$ gene transcription, most likely through interaction with the p65 subunit of nuclear factor $\mathrm{kB}(\mathrm{NF}-\mathrm{kB})$. Other mechanisms of action of calcitriol through VDR include suppression of the expression of vascular endothelial growth factor (VEGF), angiopoietin 1 and platelet-derived growth factor (PDGF) and transcriptional repression of hypoxiainducible factor 1 alpha (HIF1 $\alpha)(75)$.

It is also worth noting that the presence of a physiological concentration of calcitriol is essential for a normal $\mathrm{T}$ lymphocyte-dependent immune response, which has been shown to depend on the presence of VDR (increased risk of infectious diseases with vitamin D insufficiency) (76).

\section{Inhibition of Hedgehog (Hh) Signaling by Vitamin D}

The Hh signaling begins with the attachment of the $\mathrm{Hh}$ peptide to the Patched (Ptch) receptor. The free form of Ptch inhibits Smoothened (Smo) protein. However, after $\mathrm{Hh}$ is attached, activation of Smo occurs, which induces the transport of GLI proteins to the cell nucleus followed by attachment to DNA and induction of transcription of target genes $(77,78)$. Deregulation of Hh signaling can lead both to stimulation and progression of cancer $(79,80)$. Four different types of human cancer, related to the Hh pathway, have been described: basal cell carcinoma, medulloblastoma, rhabdomyosarcoma and meningiomas (81). These can occur via mutations in the genes encoding components of the pathway (e.g., PTH1, CLI1, HIP or SFRPl) or by excess production of the Hh ligand by the tumor or stromal cells $(80,81)$. The drugs blocking the Hh pathway are relatively new in oncological medicine $(82,83)$. The first human inhibitor of Hh signaling, GDC-0449, is now in clinical trials for at least 8 human cancers, and several other $\mathrm{Hh}$ inhibitors are in varying stages of clinical development. As early as in 2006, the inhibition of Hh signaling by vitamin $\mathrm{D}$ in vitro was described (84). The effect of Hh signaling on the growth of basal cell carcinoma (BCC) is particularly well documented $(82,85)$. Tang et al. (82) claimed that Vitamin $\mathrm{D}$ inhibits both Hh proliferation and signaling, on the basis of mRNA expression of the Hh GLII target gene. Moreover, it was emphasized that this effect was independent of the VDR receptor. Abert et al. (86) have shown that in Ptch mutant mice with basal cell carcinoma and in BCC cell lines, both Vitamin D and its active metabolite calcitriol $\left(1,25(\mathrm{OH})_{2} \mathrm{D}_{3}\right)$ exhibit an anticancer effect, mainly, by inhibiting Hh signaling.

\section{Interaction of p53 and VDR Signaling}

The p53 protein protects cells against changes in the genome due to DNA damage by inducing apoptosis, halting cell cycle progression or cellular aging (87). This protein undergoes inactivation in over $50 \%$ of cancer cases because of increased proteasomal degradation, or the presence of inactivating checkpoint mutations in its gene (88). This results, among other, in the formation of a transcriptionally inactive protein, hyperproduction of the mutant $\mathrm{p} 53$ protein or disturbance of $\mathrm{p} 53$ regulation by the chief negative regulators in the cell (by way of overexpression of binding factors - MDM2 and MDM4 (murine double minute 2 and 4 ) and the inhibition of transcription activity of the p53 protein (mainly MDM4) (8992). Mutated p53 not only loses its tumor suppressor activity, but can also acquire oncogenic functions which are defined as gain-of-function (GOF) $(93,94)$. The introduction of the TP53 gene allele with null mutation to the stem cells of mice by way of homologous recombination, resulted in a spontaneous development of cancer in $75 \%$ of mice with the p53 phenotype (-/-) before they were 6 months old (95). On the other hand, the introduction of the gene encoding the wild type p53 (wtp53) to the cell line of mouse myeloid leukemia, devoid of the active p53 protein, resulted in a drastic reduction of cell viability and of apoptosis markers including chromatin condensation, nucleus fragmentation and DNA fragmentation (96).

Thus, restoration of the tumor suppressor function of the p53 protein in cancer cells could lead to cancer remission (97). Attempts have been made to design non-protein low- 
molecular mass inhibitors of MDM2-p53 interaction, and also of MDM4-p53, that will reactivate p53 and will have potential of being anticancer drugs (98), such as for example actinomycin D (99).

Vitamin D and its analogs are also considered to be potential antineoplastic agents. The active form of vitamin $\mathrm{D}, 1,25(\mathrm{OH})_{2} \mathrm{D}_{3}$, is capable of initiating or terminating gene transcription after binding to VDR which belongs to the nuclear receptor superfamily and functions of a ligandactivated transcription factor. Maruyama et al. (100) have confirmed that expression of the VDR gene is directly regulated by $\mathrm{p} 53$ protein. Overexpression of VDR increased the response to vitamin $\mathrm{D}$ treatment and inhibited the growth of colon cancer. The VDR gene is a transcription target of wtp53 and also of p63 and p73 (100-103). It is particularly interesting, that VDR is increased in several types of cancer, including breast and ovarian cancer $(104,105)$. A mutated p53 can cause deregulation of the anticancer activity of the VDR pathway. Stambolsky et al. (106) have described the mechanism of mutp53 GOF (gain-of-function), based on the interaction between p53 and VDR. It was shown that VDR and mutp53 (and also wtp53) interact with each other and this interaction increases as a result of vitamin $D_{3}$ supplementation (106). The existence of an interaction between mutp53 and the regulation of transcription by calcitriol is probably due to the fact that mutp53 is bound to chromosome regions containing VDRE elements, probably via binding to VDR. Moreover, mutp53 increases nuclear accumulation of VDR which in some cases correlates with tumor stage $(107,108)$. In order to inhibit apoptosis, high endogenous levels of mutp53 in cancer cells probably cooperate with vitamin $\mathrm{D}$, which is additionally enhanced by supplementation. The mutp53-dependent antiapoptotic activity of vitamin D has also been observed in breast cancer MDA-MB-231 and ovarian cancer OVCAR3 cell lines (106, 109). Moreover, increased VDR nuclear accumulation due to the activity of mutp53 can occur even without the supply of calcitriol, indicating that the mutant $\mathrm{p} 53$ protein changes the conformation of the receptor in a way that imitates the activity of vitamin D. It has been emphasized that the increased nuclear accumulation of VDR is probably not the only explanation of the effect of mutp53 (106). In the case of transactivation, VDR recruits mutp53 to VDRE in target genes, whereas mutp53 increases VDR-dependent transcription, thus stimulating the recruitment of additional transcription co-activators such as p300 (p300/cyclic AMPresponse-element binding protein). The conversion of the VDR pathway from proapoptotic to antiapoptotic can occur due to a mutation in p53 GOF, at least in the cell lines which are protected by vitamin D. Undoubtedly, this discovery should be taken into account while deciding to apply therapies with vitamin D analogs for cancer. This means that apart from its well-documented proapoptotic activity, vitamin
D can also have an antiapoptotic effect, and thus the VDR pathway can lead either to the patient's death or survival, depending on the presence of a TP53 mutation (106).

\section{Vitamin D - Interaction of Photocarcinogenesis}

Over $90 \%$ of vitamin D in the human body is produced in the skin in response to sun exposure. Human epithelial cells (keratinocytes) possess a complete system for the synthesis and metabolism of vitamin D. They have receptors for vitamin D (VDR) which are responsible for inducing gene expression. Both 25-hydroxylation and 1-hydroxylation lead to the formation of a biologically active form of vitamin D known as calcitriol $\left(1,25(\mathrm{OH})_{2} \mathrm{D}_{3}\right)$ and 24-hydroxylation leads to catabolism of vitamin D. Moreover, fibroblasts of the dermis possess a mechanism that allows the formation of $25(\mathrm{OH}) \mathrm{D}_{3}$, yet they do not have 1-hydroxylase and hence are unable to produce calcitriol (110). The application of vitamin D in dermatology is mainly due to its immunomodulatory properties, as well as its effect on the regulation of cell proliferation and differentiation. Vitamin D is formed in the epidermis and, together with calcium, it participates in the process of regeneration of the epidermal barrier (which is important for the treatment of various skin disorders such as psoriasis, photodermatoses, xeroderma pigmentosum and cancers) (111). Unfortunately, the increased incidence of skin cancers is largely the effect of increased exposure to ultraviolet radiation; UVB (which penetrates through the epidermis) and UVA (which penetrates into the dermis). The effects of excessive UV exposure include erythema, sunburns and dysfunction of Langerhans cells which are a part of the immune system of the skin. On the molecular level, exposure of DNA molecules to UV radiation leads to their damage, which in the absence of efficient repair systems can result in mutations and subsequently the initiation of neoplastic processes $(112,113)$. The potential anticancer activity of calcitriol in the case of malignant melanoma have been examined in many experimental and epidemiological studies, but contrary results have also been obtained (114-120). Sunburns in childhood (before the age of 15) are the most significant risk factor, regardless of the latitude of the children's locations (120). The systemic or local administration of $1,25(\mathrm{OH})_{2} \mathrm{D}_{3}$ immediately after excessive exposure to UV radiation was found to reduce sunburns in both humans and mice $(121,122)$. Besides, the presence of at least one actinic keratosis lesion also increases the risk of melanoma development (123). However, there is no unequivalent answer to the question concerning the relationship between the risk of melanoma and taking vitamin D either in the diet or in the form of supplements (124). Similarly, no relationship was found between the risk of developing melanoma and the concentration of vitamin D in serum (125). An attempt has been made to examine the effect of vitamin D used locally on 
the skin after exposure to UV radiation. It was found that tumor development was inhibited due to a strengthening of the repair mechanisms $(126,127)$. Makarova et al. (128) found that vitamin D synthetized in the skin by UVR protects the organism against oncogenic activity by inhibiting Hh signaling, whereas vitamin D taken in the diet does not exhibit such a protective mechanism, probably due to the rapid hydroxylation reaction accompanying oral intake (129).

UV radiation induces a number of changes in the skin by generating reactive oxygen species (ROS) and nitric oxide (NO) which can provoke DNA oxidative damage and lipid peroxidation. Promutagenic pyrimidine dimers and 8-hydroxy-2'deoxyguanosine are the major forms of DNA damage produced directly by UV radiation $(122,130-132)$. Vitamin D analogs were found to decrease the levels of thymine dimers which are formed after UV exposure (133) and the frequency of occurrence of oxidative and nitration DNA damage by reducing the production of $\mathrm{NO}$ and other toxic reactive forms of nitrogen $(127,133,134)$. A decrease in DNA damage after exposure to UV radiation in the presence of $1,25(\mathrm{OH})_{2} \mathrm{D}_{3}$ has been observed in keratinocytes (127, 133), fibroblasts (135) and melanocytes (136). The protective activity of vitamin D against the sun's damaging effects to the skin also includes increase in the levels of p53 protein and metallothionein in the presence of calcitriol (127, 133, 134). A multifactorial effect of vitamin D to skin damage due to UV exposure is also related to the immune functions of the skin (among other things by its influence on maturation of the Langerhans cells presenting the antigen, NF- $\mathrm{kB}, \mathrm{T}$ lymphocytes, IL-10, monocytes, macrophages) (122).

It seems that in the case of malignant melanoma the protective activity of sunrays through the synthesis of vitamin $\mathrm{D}$ is less important than its carcinogenic activity (regardless of the amount of time spent in the sun) (137, 138). The relationship between melanoma and sun radiation is very complicated and involves both the slow genome pathways (via the VDR receptor) and the rapid non-genome responses. Further investigations are required in this respect that would take into account not only the promising aspects of vitamin D anticancer effect, but its "dark" side as well.

\section{Conclusion}

On the basis of current data, it cannot be stated conclusively whether intake of vitamin D may offer protection against cancer. The presence of the VDR throughout the body and the effect of vitamin D on the cell cycle, apoptosis, angiogenesis, Hh signaling, interaction of p53 and photocarcinogenesis unquestionably suggest such a potential. However, further research is required, first to fully elucidate the mechanisms of action of this vitamin, and secondly to determine a specific dose and time of intake necessary to achieve an anticancer effect.

\section{Conflicts of Interest}

The Authors declare no conflict of interest.

\section{Authors' Contributions}

Conception and drafting of the manuscript: Dorota Skrajnowska; Critical revision of the manuscript for important intellectual content: Barbara Bobrowska - Korczak. All Authors gave approval of the final version for submission.

\section{Acknowledgements}

None declared.

\section{References}

1 Yang S, Li A, Wang J, Liu J, Han Y, Zhang W, Li YC and Zhang H: Vitamin D receptor: A novel therapeutic target for kidney diseases. Curr Med Chem 25: 3256-3271, 2018. PMID: 29446731. DOI: $10.2174 / 0929867325666180214122352$

2 Zgaga L, Theodoratou E, Farrington SM, Din FVN, Ooi LY, Glodzik D, Johnston S, Tenesa A, Campbell H and Dunlop MG: Plasma Vitamin D concentration influences survival outcome after a diagnosis of colorectal cancer. J Clin Oncol 32: 2430-2439, 2014. PMID: 25002714. DOI: 10.1200/JCO.2013. 54.5947

3 Lappe JM, Travers-Gustafson D, Davies KM, Recker RR and Heaney RP: Vitamin D and calcium supplementation reduces cancer risk: results of a randomized trial. Am J Clin Nutr 85: 15861591, 2007. PMID: 17556697. DOI: 10.1093/ajcn/ 85.6.1586

4 Grant WB and Garland CF: The association of solar ultraviolet B (UVB) with reducing risk of cancer: multifactorial ecologic analysis of geographic variation in age-adjusted cancer mortality rates. Anticancer Res 26: 2687-2699, 2006. PMID: 16886679.

5 Fleet JC, DeSmet M, Johnson R and Li Y: Vitamin D and cancer: a review of molecular mechanisms. Biochem J 441: 6176, 2012. PMID: 22168439. DOI: 10.1042/BJ20110744

6 Welsh J: Vitamin D and breast cancer: insights from animal models. Am J Clin Nutr 80: 1721S-4S, 2004. PMID: 15585794. DOI: $10.1093 / \mathrm{ajcn} / 80.6 .1721 \mathrm{~S}$

7 Grant WB, Garland CF and Holick MF: Comparisons of estimated economic burdens due to insufficient solar ultraviolet irradiance and vitamin D and excess solar UV irradiance for the United States. Photochem Photobiol 81: 1276-1286, 2005. PMID: 16159309. DOI: 10.1562/2005-01-24-RA-424

8 Grant WB: Ecologic studies of solar UV-B radiation and cancer mortality rates. Recent Results Cancer Res Fortschritte Krebsforsch Progres Dans Rech Sur Cancer 164: 371-377, 2003. PMID: 12899536.

9 Gaschott T, Steinmeyer A, Steinhilber D and Stein J: ZK 156718 , a low calcemic, antiproliferative, and prodifferentiating Vitamin D analog. Biochem Biophys Res Commun 290: 504509, 2002. PMID: 11779200. DOI: 10.1006/bbrc.2001.6213

10 Muindi JR, Peng Y, Potter DM, Hershberger PA, Tauch JS, Capozzoli MJ, Egorin MJ, Johnson CS and Trump DL: Pharmacokinetics of high-dose oral calcitriol: results from a phase 1 trial of calcitriol and paclitaxel. Clin Pharmacol Ther 72: 648-659, 2002. PMID: 12496746. DOI: $10.1067 / \mathrm{mcp}$. 2002.129305 
11 Johnson CS, Hershberger PA and Trump DL: Vitamin D-related therapies in prostate cancer. Cancer Metastasis Rev 21: 147158, 2002. PMID: 12465754.

12 Welsh J, Wietzke JA, Zinser GM, Byrne B, Smith K and Narvaez CJ: Vitamin D-3 receptor as a target for breast cancer prevention. J Nutr 133: 2425S-2433S, 2003. PMID: 12840219. DOI: $10.1093 / \mathrm{jn} / 133.7 .2425 \mathrm{~S}$

13 Lamprecht SA and Lipkin M: Chemoprevention of colon cancer by calcium, vitamin D and folate: molecular mechanisms. Nat Rev Cancer 3: 601-614, 2003. PMID: 12894248. DOI: 10.1038/ $\operatorname{nrc} 1144$

14 Díaz GD, Paraskeva C, Thomas MG, Binderup L and Hague A: Apoptosis is induced by the active metabolite of vitamin $\mathrm{D}_{3}$ and its analogue EB1089 in colorectal adenoma and carcinoma cells: possible implications for prevention and therapy. Cancer Res 60: 2304-2312, 2000. PMID: 10786699.

15 Akutsu N, Lin R, Bastien Y, Bestawros A, Enepekides DJ, Black MJ and White JH: Regulation of gene Expression by 1alpha,25-dihydroxyvitamin $\mathrm{D}_{3}$ and Its analog EB1089 under growth-inhibitory conditions in squamous carcinoma cells. Mol Endocrinol Baltim Md 15: 1127-1139, 2001. PMID: 11435613. DOI: $10.1210 /$ mend.15.7.0655

16 Ribiczey P, Papp B, Homolya L, Enyedi Á and Kovács T: Selective upregulation of the expression of plasma membrane calcium ATPase isoforms upon differentiation and $1,25(\mathrm{OH})_{2} \mathrm{D}_{3}$-vitamin treatment of colon cancer cells. Biochem Biophys Res Commun 464: 189-194, 2015. PMID: 26116539. DOI: $10.1016 / j . b b r c .2015 .06 .113$

17 Tidow $\mathrm{H}$ and Nissen P: Structural diversity of calmodulin binding to its target sites. FEBS J 280: 5551-5565, 2013. PMID: 23601118. DOI: 10.1111/febs.12296

18 Lips P: Vitamin D physiology. Prog Biophys Mol Biol 92: 4-8, 2006. PMID: 16563471. DOI: 10.1016/j.pbiomolbio. 2006. 02.016

19 Schwartz GG: Circulating vitamin D and risk of prostate cancer--letter. Cancer Epidemiol Biomarkers Prev 21: 246; author reply 247, 2012. PMID: 22045701. DOI: $10.1158 / 1055$ 9965.EPI-11-0910

20 Skrajnowska D, Bobrowska-Korczak B and Tokarz A: Disorders of mechanisms of calcium metabolism control as potential risk factors of prostate cancer. Curr Med Chem 24: 4229-4244, 2017. PMID: 28901272. DOI: $10.2174 / 092986$ 7324666170913102834

21 Schalken JA: The androgen cascade in ageing men: Blessing or curse? Eur Urol Suppl 2: 8-12, 2003. DOI: 10.1016/j.eursup. 2003.09.009

22 Beer TM and Myrthue A: Calcitriol in cancer treatment: from the lab to the clinic. Mol Cancer Ther 3: 373-381, 2004. PMID: 15026558 .

23 Wade WN, Willingham MC, Koumenis C and Cramer SD: p27Kip1 is essential for the antiproliferative action of 1,25dihydroxyvitamin $\mathrm{D}_{3}$ in primary, but not immortalized, mouse embryonic fibroblasts. J Biol Chem 277: 37301-37306, 2002. PMID: 12163488. DOI: 10.1074/jbc.M204162200

24 Feldman D, Krishnan AV, Swami S, Giovannucci E and Feldman BJ: The role of vitamin D in reducing cancer risk and progression. Nat Rev Cancer 14: 342-357, 2014. PMID: 24705652. DOI: $10.1038 / \mathrm{nrc} 3691$

25 Marcinkowska E: A run for a membrane vitamin D receptor. Biol Signals Recept 10: 341-349, 2001. PMID: 11721090. DOI: $10.1159 / 000046902$
26 Desprez PY, Poujol D, Falette N, Lefebvre MF and Saez S: 1,25Dihydroxyvitamin $\mathrm{D}_{3}$ increases epidermal growth factor receptor gene expression in BT-20 breast carcinoma cells. Biochem Biophys Res Commun 176: 1-6, 1991. PMID: 1673338.

27 Roehrborn CG: Benign prostatic hyperplasia: An overview. Rev Urol 7: S3-S14, 2005. PMID: 16985902.

28 Li Y, Chinni SR and Sarkar FH: Selective growth regulatory and pro-apoptotic effects of DIM is mediated by AKT and NFkappaB pathways in prostate cancer cells. Front Biosci J Virtual Libr 10: 236-243, 2005. PMID: 15574364.

29 Moreno J, Krishnan AV, Peehl DM and Feldman D: Mechanisms of vitamin D-mediated growth inhibition in prostate cancer cells: inhibition of the prostaglandin pathway. Anticancer Res 26: 2525-2530, 2006. PMID: 16886660.

30 Bouillon R, Eelen G, Verlinden L, Mathieu C, Carmeliet G and Verstuyf A: Vitamin D and cancer. J Steroid Biochem Mol Biol 102: 156-162, 2006. PMID: 17113979. DOI: 10.1016/ j.jsbmb.2006.09.014

31 Danilenko $M$ and Studzinski GP: Enhancement by other compounds of the anti-cancer activity of vitamin $\mathrm{D}(3)$ and its analogs. Exp Cell Res 298: 339-358, 2004. PMID: 15265684. DOI: $10.1016 /$ j.yexcr.2004.04.029

32 Bibby MC: An introduction to telomeres and telomerase. Mol Biotechnol 24: 295-301, 2003. PMID: 12777695. DOI: 10.1385/MB:24:3:295

33 Blackburn EH: The end of the (DNA) line. Nat Struct Biol 7: 847-850, 2000. PMID: 11017190. DOI: $10.1038 / 79594$

34 Nicholls C, Li H, Wang J-Q and Liu J-P: Molecular regulation of telomerase activity in aging. Protein Cell 2: 726-738, 2011. PMID: 21976062. DOI: 10.1007/s13238-011-1093-3

35 Cai Y, Ai Y, Zhao Q, Li J, Yang G, Gong P, Wang Q, Hou H, Zhang G, Li L, Yang J, Li H, Zheng J, Li S and Zhang X: Cloning and characterization of telomerase reverse transcriptase gene in Trichinella spiralis. Parasitol Res 110: 411-417, 2012. PMID: 21748355. DOI: 10.1007/s00436-011-2506-1

36 Prüfer $\mathrm{K}$ and Barsony J: Retinoid X receptor dominates the nuclear import and export of the unliganded vitamin $\mathrm{D}$ receptor. Mol Endocrinol Baltim Md 16: 1738-1751, 2002. PMID: 12145331. DOI: $10.1210 / \mathrm{me} .2001-0345$

37 Haussler MR, Haussler CA, Jurutka PW, Thompson PD, Hsieh JC, Remus LS, Selznick SH and Whitfield GK: The vitamin D hormone and its nuclear receptor: molecular actions and disease states. J Endocrinol 154 Suppl: S57-73, 1997. PMID: 9379138.

38 Ryynänen J and Carlberg C: Primary 1,25-dihydroxyvitamin $\mathrm{D}_{3}$ response of the interleukin 8 gene cluster in human monocyteand macrophage-like cells. PloS One 8: e78170, 2013. PMID: 24250750. DOI: 10.1371/journal.pone.0078170

39 Hershberger PA, McGuire TF, Yu W-D, Zuhowski EG, Schellens JHM, Egorin MJ, Trump DL and Johnson CS: Cisplatin potentiates 1,25-dihydroxyvitamin D3-induced apoptosis in association with increased mitogen-activated protein kinase kinase kinase 1 (MEKK-1) expression. Mol Cancer Ther 1: 821-829, 2002. PMID: 12492115.

40 Ditsch N, Toth B, Mayr D, Lenhard M, Gallwas J, Weissenbacher T, Dannecker C, Friese K and Jeschke U: The association between vitamin $\mathrm{D}$ receptor expression and prolonged overall survival in breast cancer. J Histochem Cytochem 60: 121-129, 2012. PMID: 22108646. DOI: 10.1369/ 0022155411429155

41 Berkovich L, Sintov AC and Ben-Shabat S: Inhibition of cancer growth and induction of apoptosis by BGP-13 and BGP-15, 
new calcipotriene-derived vitamin $\mathrm{D}_{3}$ analogs, in vitro and in vivo studies. Invest New Drugs 31: 247-255, 2013. PMID: 22661288. DOI: $10.1007 / \mathrm{s} 10637-012-9839-1$

42 Wu-Wong JR, Tian J and Goltzman D: Vitamin D analogs as therapeutic agents: a clinical study update. Curr Opin Investig Drugs Lond Engl 2000 5: 320-326, 2004. PMID: 15083599.

43 Peehl DM, Krishnan AV and Feldman D: Pathways mediating the growth-inhibitory actions of vitamin $\mathrm{D}$ in prostate cancer. J Nutr 133: 2461S-2469S, 2003. PMID: 12840225. DOI: $10.1093 / \mathrm{jn} / 133.7 .2461 \mathrm{~S}$

44 Zhang $X$ and Giovannucci E: Calcium, vitamin D and colorectal cancer chemoprevention. Best Pract Res Clin Gastroenterol 25: 485-494, 2011. PMID: 22122765. DOI: 10.1016/j.bpg.2011.10.001

45 Lin R, Nagai Y, Sladek R, Bastien Y, Ho J, Petrecca K, Sotiropoulou G, Diamandis EP, Hudson TJ and White JH: Expression profiling in squamous carcinoma cells reveals pleiotropic effects of vitamin $\mathrm{D}_{3}$ analog EB1089 signaling on cell proliferation, differentiation, and immune system regulation. Mol Endocrinol Baltim Md 16: 1243-1256, 2002. PMID: 12040012. DOI: 10.1210/mend.16.6.0874

46 Koshiyama H, Sone T and Nakao K: Vitamin-D-receptor-gene polymorphism and bone loss. Lancet Lond Engl 345: 990-991, 1995. PMID: 7715321.

47 van den Bemd GJ, Pols HA and van Leeuwen JP: Anti-tumor effects of 1,25-dihydroxyvitamin $\mathrm{D}_{3}$ and vitamin $\mathrm{D}$ analogs. Curr Pharm Des 6: 717-732, 2000. PMID: 10828303.

48 Woloszynska-Read A, Johnson CS and Trump DL: Vitamin D and cancer: clinical aspects. Best Pract Res Clin Endocrinol Metab 25: 605-615, 2011. PMID: 21872802. DOI: 10.1016/ j.beem.2011.06.006

49 Plum LA, Prahl JM, Ma X, Sicinski RR, Gowlugari S, ClagettDame $M$ and DeLuca HF: Biologically active noncalcemic analogs of 1alpha,25-dihydroxyvitamin D with an abbreviated side chain containing no hydroxyl. Proc Natl Acad Sci USA 101: 6900-6904, 2004. PMID: 15118084. DOI: 10.1073/ pnas.0401656101

50 Gardiner EM, Esteban LM, Fong C, Allison SJ, Flanagan JL, Kouzmenko AP and Eisman JA: Vitamin D receptor B1 and exon 1d: functional and evolutionary analysis. J Steroid Biochem Mol Biol 89-90: 233-238, 2004. PMID: 15225777. DOI: $10.1016 /$ j.jsbmb.2004.03.078

51 Xiong L, Cheng J, Gao J, Wang J, Liu X and Wang L: Vitamin $D$ receptor genetic variants are associated with chemotherapy response and prognosis in patients with advanced non-smallcell lung cancer. Clin Lung Cancer 14: 433-439, 2013. PMID: 23522953. DOI: 10.1016/j.cllc.2013.01.004

52 Elmore S: Apoptosis: a review of programmed cell death. Toxicol Pathol 35: 495-516, 2007. PMID: 17562483. DOI: $10.1080 / 01926230701320337$

53 Trump DL, Hershberger PA, Bernardi RJ, Ahmed S, Muindi J, Fakih M, Yu W-D and Johnson CS: Anti-tumor activity of calcitriol: pre-clinical and clinical studies. J Steroid Biochem Mol Biol 89-90: 519-526, 2004. PMID: 15225831. DOI: 10.1016/j.jsbmb.2004.03.068

54 Gonzalez-Suarez I, Redwood AB, Grotsky DA, Neumann MA, Cheng EH-Y, Stewart CL, Dusso A and Gonzalo S: A new pathway that regulates 53BP1 stability implicates cathepsin L and vitamin D in DNA repair. EMBO J 30: 3383-3396, 2011. PMID: 21750527. DOI: 10.1038/emboj.2011.225
55 Bröker LE, Kruyt FAE and Giaccone G: Cell death independent of caspases: a review. Clin Cancer Res 11: 31553162, 2005. PMID: 15867207. DOI: 10.1158/1078-0432.CCR04-2223

56 Tokarzewicz A and Gorodkiewicz E: Proteases: significance, role and determination. CHEMIK 69: 81-88, 2015.

57 Sinha AA, Quast BJ, Wilson MJ, Fernandes ET, Reddy PK, Ewing SL and Gleason DF: Prediction of pelvic lymph node metastasis by the ratio of cathepsin B to stefin A in patients with prostate carcinoma. Cancer 94: 3141-3149, 2002. PMID: 12115346. DOI: $10.1002 /$ cncr.10604

58 Levicar N, Strojnik T, Kos J, Dewey RA, Pilkington GJ and Lah TT: Lysosomal enzymes, cathepsins in brain tumour invasion. J Neurooncol 58: 21-32, 2002. PMID: 12160137.

59 Zhu Y, Chen P, Gao Y, Ta ND, Zhang Y, Cai J, Zhao Y, Liu S and Zheng J: MEG3 activated by vitamin d inhibits colorectal cancer cells proliferation and migration via regulating clusterin. In: EBioMedicine, 2018. PMID: 29628342. DOI: 10.1016/ j.ebiom.2018.03.032

60 Abramson JS and Shipp MA: Advances in the biology and therapy of diffuse large B-cell lymphoma: moving toward a molecularly targeted approach. Blood 106: 1164-1174, 2005. PMID: 15855278. DOI: 10.1182/blood-2005-02-0687

61 Pasqualucci L, Bhagat G, Jankovic M, Compagno M, Smith P, Muramatsu M, Honjo T, Morse HC, Nussenzweig MC and Dalla-Favera R: AID is required for germinal center-derived lymphomagenesis. Nat Genet 40: 108-112, 2008. PMID: 18066064. DOI: $10.1038 / n g .2007 .35$

62 Fulda S, Meyer E and Debatin K-M: Inhibition of TRAILinduced apoptosis by Bcl-2 overexpression. Oncogene 21: 22832294, 2002. PMID: 11948412. DOI: 10.1038/sj.onc. 1205258

63 Gómez-Navarro J, Arafat W and Xiang J: Gene therapy for carcinoma of the breast: Pro-apoptotic gene therapy. Breast Cancer Res 2: 32-44, 2000. PMID: 11250691. DOI: 10.1186/bcr27

64 Müllauer L, Gruber P, Sebinger D, Buch J, Wohlfart S and Chott A: Mutations in apoptosis genes: a pathogenetic factor for human disease. Mutat Res 488: 211-231, 2001. PMID: 11397650 .

65 Chakraborti CK: Vitamin D as a promising anticancer agent. Indian J Pharmacol 43: 113-120, 2011. PMID: 21572642. DOI: 10.4103/0253-7613.77335

66 Ohnishi T, Takahashi A and Ohnishi K: Studies about space radiation promote new fields in radiation biology. J Radiat Res (Tokyo) 43 Suppl: S7-12, 2002. PMID: 12793723. DOI: 10.1269/jrr.43.s7

67 Gassmann P, Enns A and Haier J: Role of tumor cell adhesion and migration in organ-specific metastasis formation. Onkologie 27: 577-582, 2004. PMID: 15591720. DOI: $10.1159 / 000081343$

68 Eble JA and Haier J: Integrins in cancer treatment. Curr Cancer Drug Targets 6: 89-105, 2006. PMID: 16529540.

69 Hansen CM, Frandsen TL, Brünner N and Binderup L: 1 alpha,25-Dihydroxyvitamin $D_{3}$ inhibits the invasive potential of human breast cancer cells in vitro. Clin Exp Metastasis 12: 195-202, 1994. PMID: 8194194.

70 Konety BR, Lavelle JP, Pirtskalaishvili G, Dhir R, Meyers SA, Nguyen TS, Hershberger P, Shurin MR, Johnson CS, Trump DL, Zeidel ML and Getzenberg RH: Effects of vitamin D (calcitriol) on transitional cell carcinoma of the bladder in vitro and in vivo. J Urol 165: 253-258, 2001. PMID: 11125420. DOI: 10.1097/00005392-200101000-00074 
71 Young MR, Ihm J, Lozano Y, Wright MA and Prechel MM: Treating tumor-bearing mice with vitamin $\mathrm{D}_{3}$ diminishes tumorinduced myelopoiesis and associated immunosuppression, and reduces tumor metastasis and recurrence. Cancer Immunol Immunother CII 41: 37-45, 1995. PMID: 7641218.

72 Prevarskaya N, Skryma R and Shuba Y: Calcium in tumour metastasis: new roles for known actors. Nat Rev Cancer 11: 609-618, 2011. PMID: 21779011. DOI: 10.1038/nrc3105

73 Cavallaro U, Schaffhauser B and Christofori G: Cadherins and the tumour progression: is it all in a switch? Cancer Lett 176: 123-128, 2002. PMID: 11804738 .

74 Morita N, Uemura H, Tsumatani K, Cho M, Hirao Y, Okajima $\mathrm{E}$, Konishi $\mathrm{N}$ and Hiasa Y: E-cadherin and $\alpha-, \beta$ - and $\gamma$-catenin expression in prostate cancers: correlation with tumour invasion. Br J Cancer 79: 1879-1883, 1999. PMID: 10206308. DOI: $10.1038 /$ sj.bjc.6690299

75 Nabeshima $\mathrm{Y}$ and Imura $\mathrm{H}$ : alpha-Klotho: a regulator that integrates calcium homeostasis. Am J Nephrol 28: 455-464, 2008. PMID: 18160815. DOI: 10.1159/000112824

76 Baeke F, Korf H, Overbergh L, van Etten E, Verstuyf A, Gysemans $\mathrm{C}$ and Mathieu C: Human T lymphocytes are direct targets of 1,25-dihydroxyvitamin $\mathrm{D}_{3}$ in the immune system. J Steroid Biochem Mol Biol 121: 221-227, 2010. PMID: 20302932. DOI: 10.1016/j.jsbmb.2010.03.037

77 Goetz SC and Anderson KV: The primary cilium: a signalling centre during vertebrate development. Nat Rev Genet 11: 331344, 2010. PMID: 20395968. DOI: 10.1038/nrg2774

78 Haycraft CJ, Banizs B, Aydin-Son Y, Zhang Q, Michaud EJ and Yoder BK: Gli2 and Gli3 localize to cilia and require the intraflagellar transport protein polaris for processing and function. PLoS Genet 1, 2005. PMID: 16254602. DOI: 10.1371/journal.pgen.0010053

79 Jiang $\mathrm{J}$ and Hui C-C: Hedgehog signaling in development and cancer. Dev Cell 15: 801-812, 2008. PMID: 19081070. DOI: 10.1016/j.devcel.2008.11.010

80 Nolan-Stevaux O, Lau J, Truitt ML, Chu GC, Hebrok M, Fernández-Zapico ME and Hanahan D: GLI1 is regulated through Smoothened-independent mechanisms in neoplastic pancreatic ducts and mediates PDAC cell survival and transformation. Genes Dev 23: 24-36, 2009. PMID: 19136624 DOI: $10.1101 / \mathrm{gad} .1753809$

$81 \mathrm{Gu} \mathrm{D}$ and Xie J: Non-canonical Hh signaling in cancer current understanding and future directions. Cancers 7: 16841698, 2015. PMID: 26343727. DOI: 10.3390/cancers7030857

82 Tang JY, Xiao TZ, Oda Y, Chang KS, Shpall E, Wu A, So P-L, Hebert J, Bikle D and Epstein EH: Vitamin $\mathrm{D}_{3}$ inhibits hedgehog signaling and proliferation in murine Basal cell carcinomas. Cancer Prev Res (Phila) 4: 744-751, 2011. PMID: 21436386. DOI: $10.1158 / 1940-6207 . C A P R-10-0285$

83 Frampton JE and Basset-Séguin N: Vismodegib: A review in advanced basal cell carcinoma. Drugs 78: 1145-1156, 2018 PMID: 30030732. DOI: 10.1007/s40265-018-0948-9

84 Bijlsma MF, Spek CA, Zivkovic D, van de Water S, Rezaee F and Peppelenbosch MP: Repression of smoothened by patcheddependent (pro-)vitamin D3 secretion. PLoS Biol 4, 2006 PMID: 16895439. DOI: 10.1371/journal.pbio.0040232

85 Von Hoff DD, LoRusso PM, Rudin CM, Reddy JC, Yauch RL, Tibes R, Weiss GJ, Borad MJ, Hann CL, Brahmer JR, Mackey HM, Lum BL, Darbonne WC, Marsters JC, de Sauvage FJ and Low JA: Inhibition of the hedgehog pathway in advanced basal- cell carcinoma. N Eng1 J Med 361: 1164-1172, 2009. DOI: 10.1056/NEJMoa0905360

86 Albert B and Hahn H: Interaction of hedgehog and vitamin D signaling pathways in basal cell carcinomas. Adv Exp Med Biol 810: 329-341, 2014. PMID: 25207374.

87 Meulmeester E and Jochemsen AG: p53: a guide to apoptosis. Curr Cancer Drug Targets 8: 87-97, 2008. PMID: 18336191.

88 Yue X, Zhao Y, Xu Y, Zheng M, Feng Z and Hu W: Mutant p53 in cancer: Accumulation, gain-of-function, and therapy. J Mol Biol 429: 1595-1606, 2017. PMID: 28390900. DOI: 10.1016/ j.jmb.2017.03.030

89 Vousden $\mathrm{KH}$ and Lu X: Live or let die: the cell's response to p53. Nat Rev Cancer 2: 594-604, 2002. PMID: 12154352. DOI: $10.1038 / \mathrm{nrc} 864$

90 Bond GL, Hu W and Levine AJ: MDM2 is a central node in the p53 pathway: 12 years and counting. Curr Cancer Drug Targets 5: 3-8, 2005. PMID: 15720184.

91 Chène P: Inhibiting the p53-MDM2 interaction: an important target for cancer therapy. Nat Rev Cancer 3: 102-109, 2003. PMID: 12563309. DOI: 10.1038/nrc991

92 Weisz L, Oren M and Rotter V: Transcription regulation by mutant p53. Oncogene 26: 2202-2211, 2007. PMID: 17401429. DOI: 10.1038/sj.onc.1210294

93 Bossi G, Lapi E, Strano S, Rinaldo C, Blandino G and Sacchi A: Mutant p53 gain of function: reduction of tumor malignancy of human cancer cell lines through abrogation of mutant p53 expression. Oncogene 25: 304-309, 2006. PMID: 16170357. DOI: $10.1038 /$ sj.onc.1209026

94 Weisz L, Zalcenstein A, Stambolsky P, Cohen Y, Goldfinger N, Oren $M$ and Rotter V: Transactivation of the EGR1 gene contributes to mutant p53 gain of function. Cancer Res 64: 8318-8327, 2004. PMID: 15548700. DOI: 10.1158/00085472.CAN-04-1145

95 Donehower LA, Harvey M, Slagle BL, McArthur MJ, Montgomery CA, Butel JS and Bradley A: Mice deficient for p53 are developmentally normal but susceptible to spontaneous tumours. Nature 356: 215-221, 1992. PMID: 1552940. DOI: $10.1038 / 356215 \mathrm{a} 0$

96 Yonish-Rouach E, Resnitzky D, Lotem J, Sachs L, Kimchi A and Oren M: Wild-type p53 induces apoptosis of myeloid leukaemic cells that is inhibited by interleukin-6. Nature 352: 345-347, 1991. PMID: 1852210. DOI: 10.1038/352345a0

97 Gebow D, Miselis N and Liber HL: Homologous and nonhomologous recombination resulting in deletion: effects of p53 status, microhomology, and repetitive DNA length and orientation. Mol Cell Biol 20: 4028-4035, 2000. PMID: 10805745. DOI: $10.1128 / \mathrm{mcb} .20 .11 .4028-4035.2000$

98 Vassilev LT: MDM2 inhibitors for cancer therapy. Trends Mol Med 13: 23-31, 2007. PMID: 17126603. DOI: 10.1016/ j.molmed.2006.11.002

99 Choong ML, Yang H, Lee MA and Lane DP: Specific activation of the p53 pathway by low dose actinomycin D: a new route to p53 based cyclotherapy. Cell Cycle Georget Tex 8: 2810-2818, 2009. PMID: 19657224 . DOI: $10.4161 /$ cc.8.17.9503

100 Maruyama R, Toyota M, Suzuki H, Sasaki Y, Aoki F, Shinomura Y, Imai $\mathrm{K}$ and Tokino T: The functional relation of vitamin D receptor and p53 in cancer cells. Cancer Epidemiol Prevent Biomarkers 15: B133, 2006.

101 Maruyama R, Aoki F, Toyota M, Sasaki Y, Akashi H, Mita H, Suzuki H, Akino K, Ohe-Toyota M, Maruyama Y, Tatsumi H, Imai 
$\mathrm{K}$, Shinomura Y and Tokino T: Comparative genome analysis identifies the vitamin D receptor gene as a direct target of p53mediated transcriptional activation. Cancer Res 66: 4574-4583, 2006. PMID: 16651407. DOI: 10.1158/0008-5472.CAN-05-2562

102 Kommagani R, Caserta TM and Kadakia MP: Identification of vitamin D receptor as a target of p63. Oncogene 25: 3745-3751, 2006. PMID: 16462763. DOI: 10.1038/sj.onc.1209412

103 Kommagani R, Payal V and Kadakia MP: Differential regulation of vitamin $\mathrm{D}$ receptor (VDR) by the p53 Family: p73-dependent induction of VDR upon DNA damage. J Biol Chem 282: 29847-29854, 2007. PMID: 17716971. DOI: 10.1074/jbc.M703641200

104 Friedrich M, Rafi L, Tilgen W, Schmidt W and Reichrath J: Expression of 1,25-dihydroxy vitamin $\mathrm{D}_{3}$ receptor in breast carcinoma. J Histochem Cytochem Off J Histochem Soc 46: 1335-1337, 1998. PMID: 9774633. DOI: 10.1177/0022155 49804601114

105 Friedrich M, Villena-Heinsen C, Tilgen W, Schmidt W, Reichrat $\mathrm{J}$ and Axt-Fliedner R: Vitamin D receptor (VDR) expression is not a prognostic factor in breast cancer. Anticancer Res 22: 1919-1924, 2002. PMID: 12168894.

106 Stambolsky P, Tabach Y, Fontemaggi G, Weisz L, Maor-Aloni R, Siegfried Z, Sigfried Z, Shiff I, Kogan I, Shay M, Kalo E, Blandino G, Simon I, Oren M and Rotter V: Modulation of the vitamin $\mathrm{D}_{3}$ response by cancer-associated mutant $\mathrm{p} 53$. Cancer Cell 17: 273-285, 2010. PMID: 20227041. DOI: 10.1016/ j.ccr.2009.11.025

107 Menezes RJ, Cheney RT, Husain A, Tretiakova M, Loewen G, Johnson CS, Jayaprakash V, Moysich KB, Salgia R and Reid ME: Vitamin D receptor expression in normal, premalignant, and malignant human lung tissue. Cancer Epidemiol Biomarkers Prev 17: 1104-1110, 2008. PMID: 18483332. DOI: 10.1158/ 1055-9965.EPI-07-2713

108 Sahin MO, Canda AE, Yorukoglu K, Mungan MU, Sade M and Kirkali Z: 1,25 Dihydroxyvitamin $\mathrm{D}(3)$ receptor expression in superficial transitional cell carcinoma of the bladder: a possible prognostic factor? Eur Urol 47: 52-57, 2005. PMID: 15582249. DOI: 10.1016/j.eururo.2004.08.004

109 Zhang X, Li P, Bao J, Nicosia SV, Wang H, Enkemann SA and Bai W: Suppression of death receptor-mediated apoptosis by 1,25-dihydroxyvitamin $\mathrm{D}_{3}$ revealed by microarray analysis. J Biol Chem 280: 35458-35468, 2005. PMID: 16093247. DOI: 10.1074/jbc.M506648200

110 Lehmann B: Role of the vitamin $\mathrm{D}_{3}$ pathway in healthy and diseased skin - facts, contradictions and hypotheses. Exp Dermatol 18: 97-108, 2009. DOI: 10.1111/j.1600-0625.2008.00810.x

111 Piotrowska A, Wierzbicka J and Żmijewski MA: Vitamin D in the skin physiology and pathology. Acta Biochim Pol 63: 17 29, 2016. PMID: 26824295. DOI: 10.18388/abp.2015_1104

112 Ramirez CC, Federman DG and Kirsner RS: Skin cancer as an occupational disease: the effect of ultraviolet and other forms of radiation. Int $\mathrm{J}$ Dermatol 44: 95-100, 2005. PMID: 15689204. DOI: $10.1111 / \mathrm{j} .1365-4632.2005 .02301 . x$

113 Brewer JD, Habermann TM and Shanafelt TD: Lymphomaassociated skin cancer: incidence, natural history, and clinical management. Int J Dermatol 53: 267-274, 2014. PMID: 24320558. DOI: $10.1111 /$ ijd.12208

114 Giovannucci E: Vitamin D status and cancer incidence and mortality. Adv Exp Med Biol 624: 31-42, 2008. PMID: 18348445. DOI: 10.1007/978-0-387-77574-6_3
115 Tang JY, Fu T, Lau C, Oh DH, Bikle DD and Asgari MM: Vitamin D in cutaneous carcinogenesis: Part I. J Am Acad Dermatol 67: 803.e1-816, 2012. PMID: 23062903. DOI: 10.1016/j.jaad.2012.05.044

116 Lerche CM, Philipsen PA, Poulsen T and Wulf HC: Topical hydrocortisone, clobetasol propionate, and calcipotriol do not increase photocarcinogenesis induced by simulated solar irradiation in hairless mice. Exp Dermatol 19: 973-979, 2010. PMID: 20113348. DOI: 10.1111/j.1600-0625.2009.01034.x

117 Pommergaard HC, Burcharth J, Rosenberg J and Raskov H: Topical treatment with diclofenac, calcipotriol (vitamin- $\mathrm{D}_{3}$ analog) and difluoromethylornithine (DFMO) does not prevent nonmelanoma skin cancer in mice. Cancer Invest 31: 92-96, 2013. PMID: 23362949. DOI: 10.3109/07357907.2012.762782

118 Reichrath J and Nürnberg B: Cutaneous vitamin D synthesis versus skin cancer development: The Janus faces of solar UV-radiation. Dermatoendocrinol 1: 253-261, 2009. PMID: 20808512.

119 Osborne JE and Hutchinson PE: Vitamin D and systemic cancer: is this relevant to malignant melanoma? $\mathrm{Br} \mathrm{J}$ Dermatol 147: 197-213, 2002. PMID: 12174089.

120 Chang Y, Barrett JH, Bishop DT, Armstrong BK, Bataille V, Bergman W, Berwick M, Bracci PM, Elwood JM, Ernstoff MS, Gallagher RP, Green AC, Gruis NA, Holly EA, Ingvar C, Kanetsky PA, Karagas MR, Lee TK, Le Marchand L, Mackie RM, Olsson H, Østerlind A, Rebbeck TR, Sasieni P, Siskind V, Swerdlow AJ, Titus-Ernstoff L, Zens MS and Newton-Bishop JA: Sun exposure and melanoma risk at different latitudes: a pooled analysis of 5700 cases and 7216 controls. Int J Epidemiol 38: 814-830, 2009. PMID: 19359257. DOI: 10.1093/ ije/dyp 166

121 Dixon KM, Deo SS, Norman AW, Bishop JE, Halliday GM, Reeve VE and Mason RS: In vivo relevance for photoprotection by the vitamin D rapid response pathway. J Steroid Biochem Mol Biol 103: 451-456, 2007. PMID: 17223553. DOI: 10.1016/j.jsbmb.2006.11.016

122 Mason RS and Reichrath J: Sunlight vitamin D and skin cancer. Anticancer Agents Med Chem 13: 83-97, 2013. PMID: 23094924.

123 Bataille V, Winnett A, Sasieni P, Newton Bishop JA and Cuzick $\mathrm{J}$ : Exposure to the sun and sunbeds and the risk of cutaneous melanoma in the UK: a case-control study. Eur J Cancer Oxf Engl 1990 40: 429-435, 2004. PMID: 14746862.

124 Asgari MM, Maruti SS, Kushi LH and White E: A cohort study of vitamin D intake and melanoma risk. J Invest Dermatol 129: 1675-1680, 2009. PMID: 19194478. DOI: 10.1038/jid.2008.451

125 Reichrath J and Querings K: No evidence for reduced 25hydroxyvitamin D serum level in melanoma patients. Cancer Causes Control CCC 15: 97-98, 2004. PMID: 15049326.

126 Kim JS, Jung M, Yoo J, Choi EH, Park BC, Kim MH and Hong SP: Protective effect of topical vitamin $\mathrm{D}_{3}$ against photocarcinogenesis in a murine model. Ann Dermatol 28: 304313, 2016. PMID: 27274628. DOI: 10.5021/ad.2016.28.3.304

127 Dixon KM, Norman AW, Sequeira VB, Mohan R, Rybchyn MS, Reeve VE, Halliday GM and Mason RS: $1 \alpha, 25(\mathrm{OH})_{2-}$ vitamin $\mathrm{D}$ and a nongenomic vitamin $\mathrm{D}$ analogue inhibit ultraviolet radiation-induced skin carcinogenesis. Cancer Prev Res (Phila) 4: 1485-1494, 2011. PMID: 21733837. DOI: 10.1158/1940-6207.CAPR-11-0165

128 Makarova A, Wang G, Dolorito JA, Kc S, Libove E and Epstein EH: Vitamin $D_{3}$ produced by skin exposure to UVR inhibits 
murine basal cell carcinoma carcinogenesis. J Invest Dermatol 137: 2613-2619, 2017. PMID: 28774592. DOI: 10.1016/ j.jid.2017.05.037

129 Bijlsma MF and Roelink H: Skin-derived vitamin $\mathrm{D}_{3}$ protects against basal cell carcinoma. J Invest Dermatol 137: 2469-2471, 2017. PMID: 29169462. DOI: 10.1016/j.jid.2017.07.816

130 Besaratinia A, Kim S-I and Pfeifer GP: Rapid repair of UVAinduced oxidized purines and persistence of UVB-induced dipyrimidine lesions determine the mutagenicity of sunlight in mouse cells. FASEB J 22: 2379-2392, 2008. PMID: 18326785. DOI: $10.1096 / \mathrm{fj} .07-105437$

131 Mason RS, Sequeira VB, Dixon KM, Gordon-Thomson C, Pobre K, Dilley A, Mizwicki MT, Norman AW, Feldman D, Halliday GM and Reeve VE: Photoprotection by 1alpha,25dihydroxyvitamin $\mathrm{D}$ and analogs: further studies on mechanisms and implications for UV-damage. J Steroid Biochem Mol Biol 121: 164-168, 2010. PMID: 20399269. DOI: 10.1016/j.jsbmb.2010.03.082

132 Agar NS, Halliday GM, Barnetson RS, Ananthaswamy HN, Wheeler M and Jones AM: The basal layer in human squamous tumors harbors more UVA than UVB fingerprint mutations: a role for UVA in human skin carcinogenesis. Proc Natl Acad Sci USA 101: 4954-4959, 2004. PMID: 15041750. DOI: 10.1073/ pnas.0401141101

133 Gupta R, Dixon KM, Deo SS, Holliday CJ, Slater M, Halliday GM, Reeve VE and Mason RS: Photoprotection by 1,25 dihydroxyvitamin $\mathrm{D}_{3}$ is associated with an increase in p53 and a decrease in nitric oxide products. J Invest Dermatol 127: 707715, 2007. PMID: 17170736. DOI: 10.1038/sj.jid.5700597
134 Halliday GM: Inflammation, gene mutation and photoimmunosuppression in response to UVR-induced oxidative damage contributes to photocarcinogenesis. Mutat Res 571: 107-120, 2005. PMID: 15748642. DOI: 10.1016/j.mrfmmm.2004.09.013

135 Wong G, Gupta R, Dixon KM, Deo SS, Choong SM, Halliday GM, Bishop JE, Ishizuka S, Norman AW, Posner GH and Mason RS: 1,25-Dihydroxyvitamin D and three low-calcemic analogs decrease UV-induced DNA damage via the rapid response pathway. J Steroid Biochem Mol Biol 89-90: 567-570, 2004. PMID: 15225840. DOI: 10.1016/j.jsbmb.2004.03.072

136 Dixon KM, Deo SS, Wong G, Slater M, Norman AW, Bishop JE, Posner GH, Ishizuka S, Halliday GM, Reeve VE and Mason RS: Skin cancer prevention: a possible role of 1,25dihydroxyvitamin $\mathrm{D}_{3}$ and its analogs. J Steroid Biochem Mol Biol 97: 137-143, 2005. PMID: 16039116. DOI: 10.1016/j.jsbmb.2005.06.006

137 Grant WB: An estimate of premature cancer mortality in the U.S. due to inadequate doses of solar ultraviolet-B radiation. Cancer 94: 1867-1875, 2002. PMID: 11920550.

138 Eide MJ and Weinstock MA: Association of UV index, latitude, and melanoma incidence in nonwhite populations--US Surveillance, Epidemiology, and End Results (SEER) Program, 1992 to 2001. Arch Dermatol 141: 477-481, 2005. PMID: 15837865. DOI: 10.1001/archderm.141.4.477

Received March 15, 2019

Revised May 21, 2019

Accepted May 23, 2019 